\title{
The Role of School in Shaping Prosocial and Civic Attitudes among Young People
}

\author{
Katarzyna Słania \\ University of Silesia in Katowice
}

\begin{abstract}
In addition to the family, school is one of the basic educational environments for a young person. She should prepare students to "be an employee (45\%), group member (34\%) and citizen (28\%), although self-development (14\%) and politically active (11\%) (Prokosz, 2011, p. 190) ". It can be said that school plays a significant role in human development, based on the foundations that he took from his family home. Zbigniew Kwieciński (2000) believes that contemporary school needs a sensitive, attentive and patient teacher who will be a guide, advisor and good listener for his students, but also one who can share his experience with them. In my doctoral research on the participation of young people, I made over 20 interviews with youth leaders operating in youth councils of cities and communes (MRM and MRG) in the Silesia area in Poland. It turned out that in many cases it is teachers who play a key role in undertaking social activity of young people. They often inspire, motivate and support young people during their activities. During the conference I would like to present a poster and pass on the results of my research on the social activity of young people and the role of school and teachers in shaping prosocial and civic attitudes among young people.
\end{abstract}

Keywords: citizenship; leadership; participation; school; youth 